\title{
FORMULATION DEVELOPMENT \& EVALUATION OF EFFERVESCENT TABLET OF ALENDRONATE SODIUM WITH VITAMIN D
}

\author{
Thoke Sagar B. ${ }^{* 1}$, Sharma Yogesh P. ${ }^{1}$, Dr. Rawat Swati S. ${ }^{1}$, Nangude Satish L. ${ }^{2}$ \\ ${ }^{1}$ S.N.D. College of Pharmacy, Babhulgaon, Yeola. Tal.- Yeola, Dist.- Nashik. 423401 \\ ${ }^{2}$ SciTech Specialties Pvt. Ltd., Musalgan MIDC, Sinnar. Tal.- Sinnar, Dist.- Nashik. 422122 \\ E-mail:- thokesagar7@gmail.com, Contact no.:- 8275584727
}

\begin{abstract}
:
Alendronate sodium is a bisphosphonates which has antiresorptive effect which is implicated in the prophylaxis and treatment of osteoporosis. The objective of this study was to formulate effervescent tablet of Alendronate sodium with Vitamin $\mathrm{D}_{3}$ against osteoporosis thereby improving patient compliance. As per revised definition proposed to US FDA, Effervescent tablet is a tablet intended to be dissolved or dispersed in water before administration. Effervescent tablets were formulated using citric acid and sodium bicarbonate as effervescent composition by wet granulation. The drug-excipient compatibility study done by DSC \& FTIR analysis and it reveals absence of interaction between the drug and excipients. The flowability study of precompression blend shows good flow properties. Formulation was evaluated for weight variation, thickness, hardness, solution time, $\mathrm{pH}$ of solution \& content uniformity. All the evaluation parameters were within the limit and complies specifications as per U.S.P. \& B.P. From the Stability analysis may be inferred that there was no degradation and change in the formulation. The Effervescent tablet of Sodium Alendronate and Vitamin $\mathrm{D}_{3}$ is a new pharmaceutical formulation to be taken orally and offering a considerable advantage: avoidance of gastro-intestinal disorders, to the limits of the possible. As compared to the pure drug and marketed tablet, this formulation displayed significantly effective in the oral osteoporosis treatment in post menopausal women.

Keywords: Alendronate sodium, Vitamin $\mathrm{D}_{3}$. Effervescent tablet, Osteoporosis.
\end{abstract}

\section{INTRODUCTION:}

The oral dosage forms are the most popular way of drug administration despite having some disadvantages like slow absorption and thus onset of action is prolong. This can be overcome by administrating the drug in liquid from but, many APIs have limited level of stability in liquid form. So, Effervescent tablets acts as an alternative dosage form. ${ }^{1}$ As per revised definition proposed to US FDA, Effervescent tablet is a tablet intended to be dissolved or dispersed in water before administration. In addition to active ingredients, it generally contains mixture of acids/acid salts and carbonate and hydrogen carbonates which release carbon dioxide when mixed with water. ${ }^{2}$ Effervescence is the evolution of gas bubbles from a liquid, as the result of a chemical reaction.

$$
\begin{aligned}
\mathrm{C}_{6} \mathrm{H}_{8} \mathrm{O}_{7}(\mathrm{aq})+3 \mathrm{NaHCO}_{3}(\mathrm{aq}) \rightarrow \mathrm{Na}_{3} \mathrm{C}_{6} \mathrm{H}_{5} \mathrm{O}_{7}(\mathrm{aq})+4 \mathrm{H}_{2} \mathrm{O} \\
+3 \mathrm{CO}_{2}(\mathrm{~g}) \uparrow
\end{aligned}
$$

Citric acid + Sodium bicarbonate $\rightarrow$ Sodium citrate +

$$
\text { Water + Carbon dioxide }{ }^{3}
$$

This reaction occurs in presence of water, even with small amount as catalyzing agent, and because water is one of the reaction products, it accelerates the rate of reaction, leading to difficulty in stopping the reaction. For this reason, the whole manufacturing and storage of effervescent products is planned by minimizing the contact with water. ${ }^{3}$

Alendronate sodium is a BCS class III bisphosphonate, used in the treatment of osteoporosis. ${ }^{5,6}$ Which acts as a potent, specific inhibitor of osteoclast-mediated bone resorption. ${ }^{4}$ Colecalciferol (vitamin $\mathrm{D}_{3}$ ) is a secosterol that is the natural precursor of the calcium-regulating hormone calcitriol (1,25-dihydroxyvitamin $\left.\mathrm{D}_{3}\right){ }^{7}$ Peter C. P. et al., examine the possible mechanism for the esophageal adverse events reported with alendronate sodium tablets and the animal studies showed that under low $\mathrm{pH}$ conditions alendronate sodium can cause esophageal irritation. ${ }^{8}$ This study seeks to formulate effervescent tablet of Alendronate sodium with cholecalciferol, which limits the amount of time in which the bisphosphonate is in contact with the Oesophageal tissue, thus minimizing the risk of irritation ${ }^{9}$ and provide vitamin $\mathrm{D}_{3}$ nutrition during bisphosphonate treatment to facilitate normal bone CODEN (USA): JDDTAO 
formation and mineralization while minimizing the occurrence of or potential for the complications associated with vitamin D insufficiency, such as hypocalcaemia and osteomalacia. $^{10}$

\section{MATERIAL AND METHODS MATERIALS:}

Alendronate sodium trihydrate was obtained from Apex Healthcare Ltd., Ankleshwar (Gujarat), as a gift sample. Vitamin $\mathrm{D}_{3}$, Citric acid, PVP-K30, Sodium bicarbonate, Sodium saccharine, Malic acid, Maltodextrin, Sodium metabisulphite, Boric acid, Sodium benzoate, color and flavor were procured from SciTech Specialities Pvt. Ltd., Sinnar (Maharashtra). All the APIs and excipients used were of analytical grade.

\section{METHODS:}

\section{DRUG-EXCIPIENT COMPATIBILITY STUDY:}

Drug-Excipient Compatibility Study by FTIR: The IR spectrum of drug as well as sample (drug and excipient) was recorded using FTIR spectrophotometer (Bruker, ALPHA, ECO-ATR) with diffuse reflectance principle. Sample was placed in the sample holder and the spectrum was scanned over a frequency range $4000-400 \mathrm{~cm}^{-1} \cdot{ }^{11,12}$
Drug-Excipient Compatibility Study by DSC:

The DSC study was carried out using Mettler Toledo DSC $822 \mathrm{e}$ differential scanning calorimeter with thermal analyzer. The samples (drug and excipients) were heated in sealed aluminum pans under nitrogen flow $(20 \mathrm{ml} / \mathrm{min})$ at a scanning rate of $10^{\circ} \mathrm{C} / \mathrm{min}$ from 0 to $300^{\circ} \mathrm{C}$. Empty aluminum pan was used as a reference. The heat flow as a function of temperature was measured for the samples. ${ }^{11-13}$

\section{FORMULATION DEVELOPMENT:}

Dispense all required materials according to doerscheckers system. Then shift the materials as per the sequence and specified mesh sieves. Mix alendronate sodium with citric acid in octagonal blender (20, Anish Pharma) \& granulated with PVP K30 in rapid mixer granulator (20, Anish Pharma). Then it was dried in a Fluidize Bed Dryer (20, Anish Pharma). Also blend 'B' was mixed in an octagonal blender.

Then blend ' $A$ ' \& ' $B$ ' were mixed with each other and blended with lubrication blend. Final blend was compressed with tablet Compression machine (Accura D4, Fluidpack) and packed with strip packaging machine (4 RACK GMP, Vilas Engg.).

Table 1: Composition of formulations F1-F10

\begin{tabular}{|c|c|c|c|c|c|c|c|c|c|c|}
\hline \multirow[t]{2}{*}{ Ingredients } & \multicolumn{10}{|c|}{ Formulation (mg/tab.) } \\
\hline & F1 & F2 & F3 & F4 & F5 & F6 & F7 & F8 & F9 & F10 \\
\hline \multicolumn{11}{|l|}{ Blend ' $A$ ' } \\
\hline Sod. alendronate & 91.37 & 91.37 & 91.37 & 91.37 & 91.37 & 91.37 & 91.37 & 91.37 & 91.37 & 91.37 \\
\hline Citric acid & 2000.76 & 1880.8 & 1763.59 & 1658.99 & 1562.56 & 1531.49 & 1651.17 & 1671.7 & 1653.13 & 1672.67 \\
\hline PVP K30 & 2.15 & 4.3 & 6.45 & 4.3 & 4.3 & 4.3 & 4.3 & 4.3 & 4.3 & 4.3 \\
\hline Water & q.s. & q.s. & q.s. & q.s. & q.s. & q.s. & q.s. & q.s. & q.s. & q.s. \\
\hline \multicolumn{11}{|l|}{ Blend ' $B$ ' } \\
\hline Sod. bicarbonate & 1818.87 & 1880.78 & 1939.94 & 1990.79 & 2031.32 & 2144.09 & 1981.41 & 2006.03 & 1983.75 & 2007.21 \\
\hline Sod. saccharine & 4.3 & 8.6 & 12.9 & 17.2 & 21.5 & 17.2 & 12.9 & 17.2 & 15.05 & 15.05 \\
\hline Vitamin $\mathrm{D}_{3}$ & 2 & 2 & 2 & 2 & 2 & 2 & 2 & 2 & 2 & 2 \\
\hline Malic acid & - & 4.3 & 8.6 & 12.9 & 17.2 & 21.5 & 25.8 & 21.5 & 21.5 & 21.5 \\
\hline Maltodextrin & 172 & 172 & 172 & 172 & 172 & 172 & 172 & 172 & 172 & 172 \\
\hline Sod. metabisulphite & 8.6 & 8.6 & 8.6 & 8.6 & 8.6 & 8.6 & 8.6 & 8.6 & 8.6 & 8.6 \\
\hline Sunset yellow color & 2.15 & 2.15 & 2.15 & 2.15 & 2.15 & 2.15 & 2.15 & 2.15 & 2.15 & 2.15 \\
\hline Orange flavor & 43 & 86 & 129 & 172 & 215 & 129 & 172 & 129 & 172 & 129 \\
\hline Polomint flavor & 4.3 & 8.6 & 12.9 & 17.2 & 21.5 & 25.8 & 25.8 & 23.65 & 23.65 & 23.65 \\
\hline \multicolumn{11}{|l|}{ Lubrication blend } \\
\hline Boric acid & 129 & 129 & 129 & 129 & 129 & 129 & 129 & 129 & 129 & 129 \\
\hline Sod. benzoate & 21.5 & 21.5 & 21.5 & 21.5 & 21.5 & 21.5 & 21.5 & 21.5 & 21.5 & 21.5 \\
\hline Total & 4300 & 4300 & 4300 & 4300 & 4300 & 4300 & 4300 & 4300 & 4300 & 4300 \\
\hline
\end{tabular}




\section{Blend ' $A$ '}

Shifting

Alendronate sodium \& Citric acid through sieve no. $100 \& 60$

Mixing

Alendronate sodium \& Citric acid in a Octagonal blender for $10 \mathrm{~min}$. at $15 \mathrm{rpm}$

\section{Granulation}

Using PVP K30 aq. Solution

in a Rapid Mixing Granulator

Drying

Blend ' $\mathrm{A}$ ' in a Fluidize Bed Dryer product bed temp. $45^{\circ} \mathrm{C}$ for $35 \mathrm{~min}$.
Blend ' $B$ '

Shifting

Sodium Bicarbonate

through sieve no. 60

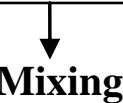

Blend ' $\mathrm{B}$ ' in a Octagonal blender for $10 \mathrm{~min}$. at $20 \mathrm{rpm}$

Mixing

Blend ' $A$ ' \& Blend ' $B$ ' in a

Octagonal blender for $15 \mathrm{~min} .24 \mathrm{rpm}$

Mixing

Mixture of Blend 'A'\&'B' with Lubrication

Blend in a Octagonal blender for $5 \mathrm{~min} .24 \mathrm{rpm}$

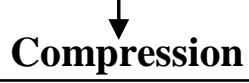

Using $25 \mathrm{~mm}$ flat punches at 4.6 AMP compression force

Packaging

In a $40 \mu$, 2ply aluminium foil having total GSM 138

Figure 1: Process flow chart 
III. EVALUATION OF PRECOMPRESSION BLEND:

\section{1) Angle of repose:}

It was measured by fixed funnel method. The fixed funnel method employ a funnel that was secured with its tip at a given height ' $h$ ', above graph paper that was placed on a flat horizontal surface. Granules were carefully poured through the funnel until the apex of the conical pile just touches the tip of the funnel. Thus, with ' $r$ ' being the radius of the base of the conical pile. ${ }^{14}$

\section{$\tan \theta=\mathbf{h} / \mathbf{r}$}

Where, $\theta=$ angle of repose

2) Bulk density: an accurately weighed sample of granulation was carefully added to the measuring cylinder with the aid of funnel. The level was observed without compacting and noted as apparent volume $\left(\mathrm{V}_{0}\right) .^{14,15}$

The bulk density was calculated by the formula as given below:

\section{Bulk density $=M / V_{0}$}

Where, $\mathrm{M}=$ Mass of powder taken. $\mathrm{V}_{0}=\quad$ Apparent untapped volume.

3) Tapped density: After bulk density measurement the cylinder was placed on the tapped density tester (ETD 1060, Electrolab) and was mechanically tapped. The cylinder was tapped for 500 times initially and the tapped volume $\left(\mathrm{V}_{1}\right)$ was measured to the nearest graduated units. The tapping was repeated for additional 750 times and the tapped volume $\left(\mathrm{V}_{2}\right)$ nearest to graduated units was noted. $^{15}$

The tapped density was calculated by the formula as given below:

\section{Tapped density $=\mathrm{M} /$}

\section{$\mathbf{V}_{2}$}

Where,

$\mathrm{M}=$ Weight of powder. $\quad \mathrm{V}_{2}=$ Tapped volume (after 750 taps).

4) Carr's Index: The percentage compressibility of a powder is direct measure of the potential of powder arch or bridge strength is calculated according to the equation given below: ${ }^{14-16}$

$\%$ Compressibility $=\frac{\text { Tapped density } \cdot \text { Bulk density }}{\text { Tapped density }} 100$ Tapped density

5) Hausner's ratio: Hausner found that the ratio tapped density/bulk density was related to inter particle friction as such, could be used to predict powder flow properties.

The Hausner's ratio was calculated by the formula as given below: ${ }^{16}$

\section{Hausner's ratio $=\frac{\text { Tapped density }}{\text { Bulk density }}$}

\section{EVALUATION OF FORMULATION:}

\section{1) Tablet Dimensions:}

Ten tablets of each formulation were evaluated for thickness and diameter using a calibrated dial caliper. ${ }^{1}$

\section{2) Weight Variation:}

Twenty tablets were selected randomly. Tablets were weighed individually and average weight was calculated. Then deviation of each tablet from average weight was calculated and percent deviation was computed. ${ }^{17}$

\section{3) Tablet Hardness:}

The hardness was evaluated using Monsanto (VHT1,Veego) hardness tester. ${ }^{18}$

\section{4) $\mathrm{pH}$ of the Solution:}

$\mathrm{pH}$ solution was determined with one tablet in $200 \mathrm{ml}$ of purified water at $20 \pm 1{ }^{\circ} \mathrm{C}$ by using $\mathrm{pH}$ meter (HI 2211, HANNA), immediately after completing the dissolution time $^{17}$

\section{5) Solution Time:}

The solution time is indicating the time required to dissolve the tablet in $200 \mathrm{ml}$ of water at $17.5 \pm 2.5^{\circ} \mathrm{C}{ }^{18}$

\section{6) Drug Content Uniformity:}

\section{Drug content analysis of Alendronate sodium:}

Weigh and powder 20 tablets. Weigh accurately a quantity of the powder containing about $25 \mathrm{mg}$ of Alendronate sodium was taken in a $25 \mathrm{ml}$ volumetric flask and dissolved in around $15 \mathrm{ml}$ of distilled water, finally filled up to the mark by distilled water to get a 
sample solution of $1 \mathrm{mg} / \mathrm{ml}$. Then appropriate dilutions was done from the sample solution using sodium-1,2napthoquinone-4-sulphonate reagent and $0.01 \mathrm{M} \mathrm{NaOH}$. Absorbance of the resulting brown colored solution was measured at $525 \mathrm{~nm}$ using double beam UV spectrophotometer (1600, shimadzu) against a blank. ${ }^{19}$

\section{Drug content analysis of Vitamin $D_{3}$ :}

Weigh and powder 10 tablets. Weigh accurately about $12.5 \mathrm{gm}$ of the powder into a $100 \mathrm{ml}$ volumetric flask and sufficient amount of Methanol: water (97:3) was added to dissolve properly. Then appropriate dilution was done and analyzed by HPLC instrument (Shimadzu LC2010A) at $264 \mathrm{~nm}$.

\section{7) Panel Testing (Human Subjects):}

In vivo taste evaluation carried out on a trained taste panel of 5 healthy volunteers with organoleptic sense, with their prior consent. On placing the dosage form in mouth for 60 seconds, bitterness recorded against pure drug. $^{21}$

V. STABILITY STUDIES: The optimized formulations sealed in aluminum packaging and kept in the stability chamber (CHM-6S, Remi) maintained at $25^{\circ} \mathrm{C} / 60 \% \mathrm{RH}$, $30^{\circ} \mathrm{C} / 65 \% \mathrm{RH}$ and $40^{\circ} \mathrm{C} / 75 \% \mathrm{RH}$ conditions for three months. The samples of 20 tablets were randomly withdrawn on initial stage, after one month and three months. These samples were analyzed for the physical appearance, hardness, solution time, $\mathrm{pH}$ of solution and drug content. ${ }^{13,22}$

\section{RESULT \& DISCUSSION:}

\section{PREFORMULATION STUDY OF Alendronate} sodium \& Vitamin $D_{3}$ :

Alendronate is a white, crystalline, nonhygroscopic powder. Melting point of ALS observed in between 258$262{ }^{\circ} \mathrm{C}$, it complies the standard. Colecalciferol is a white, crystalline, odourless powder. Melting point of Colecalciferol observed in between $83-86{ }^{\circ} \mathrm{C}$, it complies the standard.

\section{DRUG-EXCIPIENT COMPATIBILITY STUDY:}

DSC Analysis

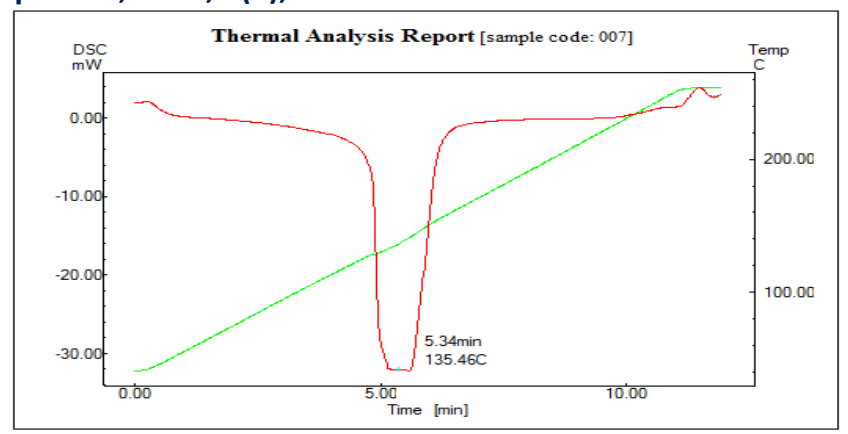

Figure 2: DSC thermogram of Alendronate sodium

The DSC thermogram of Alendronate sodium (figure 2), showed an endothermic peak in the temperature region from $76^{\circ} \mathrm{C}$ to $115^{\circ} \mathrm{C}$. It is followed by an irregular endothermic peak with shoulders at $135.46^{\circ} \mathrm{C}$ that corresponds to loss of coordinated and crystal water. The third endothermic peak, corresponding to melting of the drug is at $261^{\circ} \mathrm{C}$.

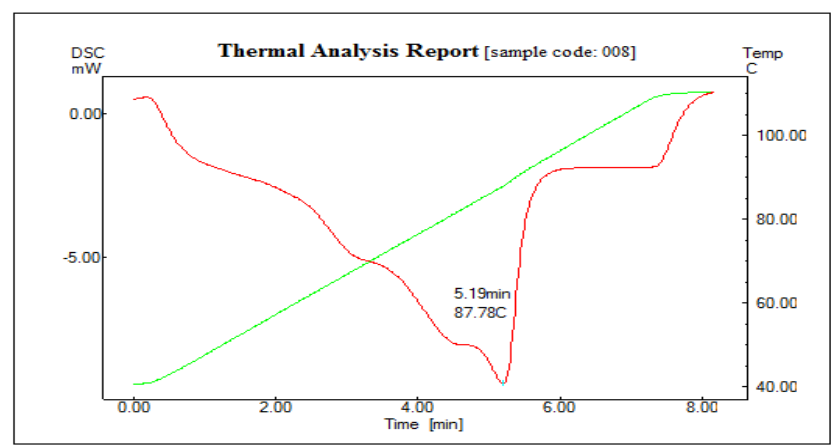

Fig. 3: DSC thermogram of Vitamin $D_{3}$

The DSC thermogram of Vitamin $\mathrm{D}_{3}$ (figure 3), showed endothermic peak, corresponding to melting of the drug is at $87.78^{\circ} \mathrm{C}$.

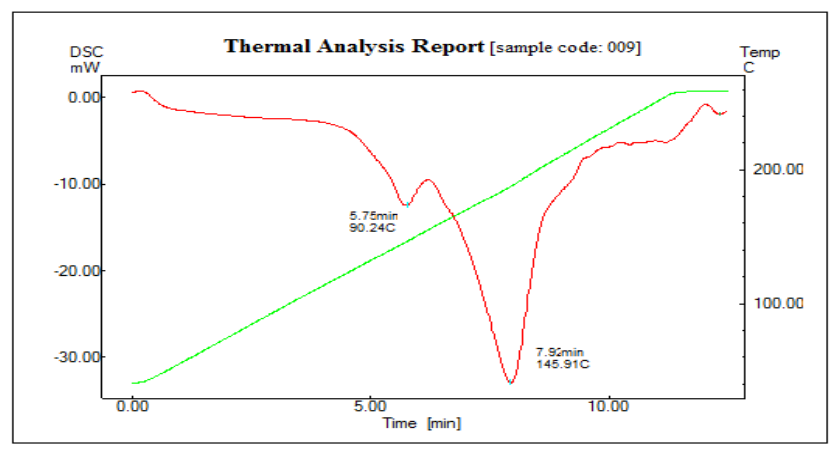

Figure 4: DSC thermogram of Alendronate sodium, Vitamin $D_{3}$ \& Excipient mixture

The DSC thermogram of Alendronate sodium, Vitamin $\mathrm{D}_{3}$ \& Excipient mixture (figure 4), showed endothermic peak, corresponding to melting of the Vitamin $\mathrm{D}_{3}$ is at $90.24^{\circ} \mathrm{C}$. It is followed by an irregular endothermic peak with shoulders at $145.91{ }^{\circ} \mathrm{C}$ that corresponds to loss of coordinated and crystal water. The third endothermic peak, corresponding to melting of the Alendronate sodium is at $261^{\circ} \mathrm{C}$. 


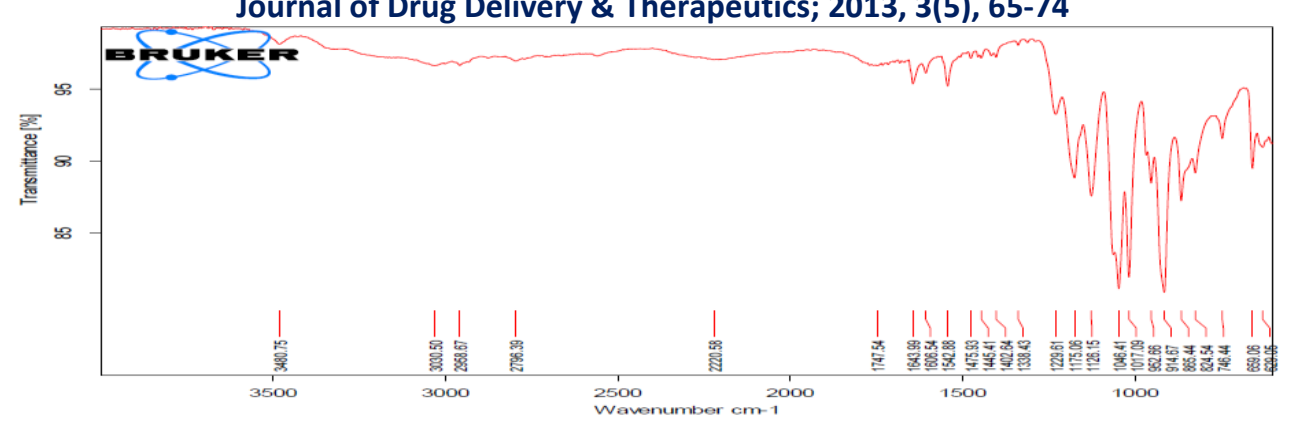

Figure 5: FTIR spectra of Alendronate sodium

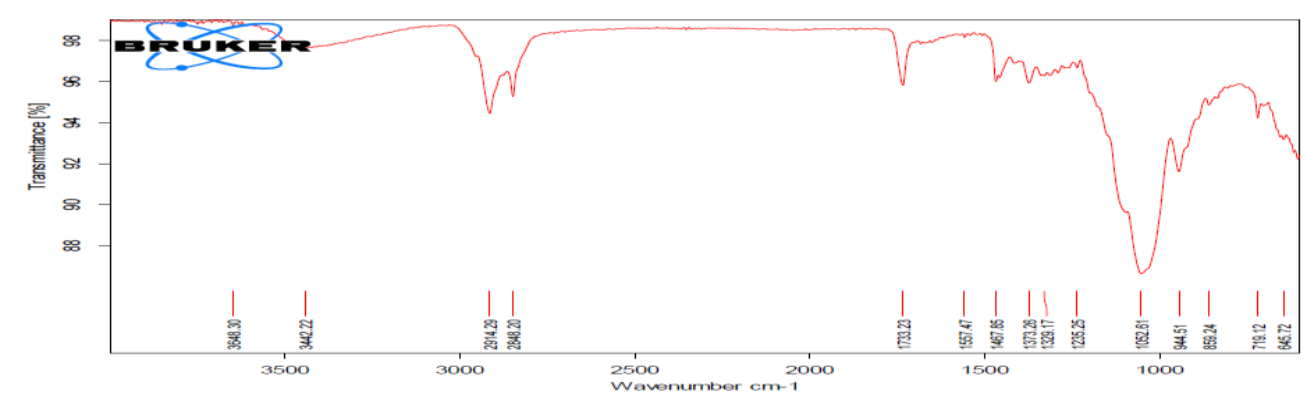

Figure 6: FTIR spectra of Vitamin $D_{3}$

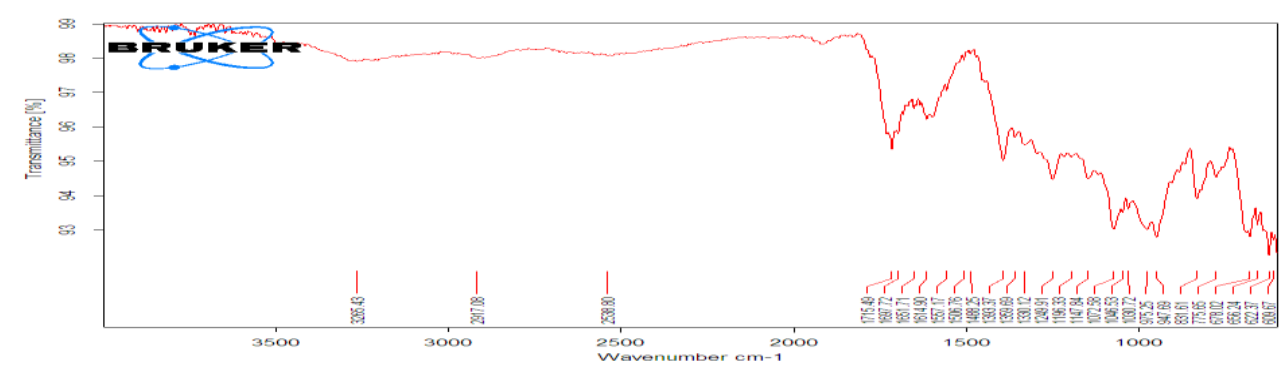

Figure 7: FTIR spectra of Alendronate sodium: $\operatorname{VitaminD}_{3}(1: 1)$ mixture

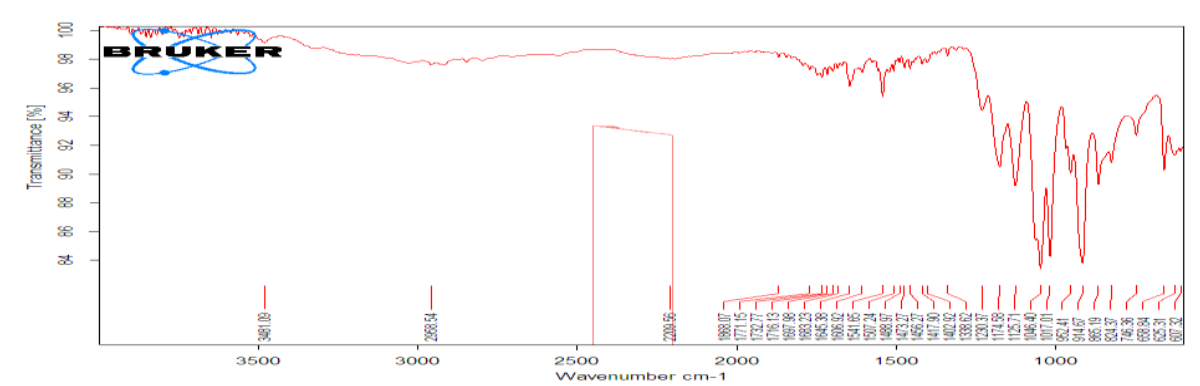

Figure 8: FTIR spectra of Alendronate sodium, Vitamin $D_{3}$ \& Excipient mixture

Table 2: Interpretation of FTIR

\begin{tabular}{|c|l|l|l|}
\hline Sr. No. & \multicolumn{1}{|c|}{ Functional group } & \multicolumn{1}{|c|}{$\begin{array}{c}\text { Standard IR range } \\
\left(\mathbf{c m}^{-\mathbf{1}}\right)\end{array}$} & \multicolumn{1}{|c|}{ Observed wave number $\left(\mathbf{c m}^{-\mathbf{1}}\right)$} \\
\hline 1. & N-H str. Amine & $3300-3500$ & $3480.75,3481.09$ \\
\hline 2. & C-H str. Alkenes & $3010-3100$ & 3030.50 \\
\hline 3. & C-N str. Amine & $1070-1150$ & $1126.15,1125.71,1072.85$ \\
\hline 4. & O-H str. Amine & $3200-3550$ & 3480.75, \\
\hline 5. & C-C str. & $1110-1250$ & $1229.61,1235.25$ \\
\hline 6. & C-H str. Alkane & $2850-2960-$ & $2914.29,2958.54,2917.08$ \\
\hline 7. & O-H str. Alcohol & $3200-3550$ & $3442.22,3481.09,3265.43$ \\
\hline
\end{tabular}


III. EVALUATION OF PRECOMPRESSION BLEND:

Table 3: Precompression evaluation of blend

\begin{tabular}{|c|l|l|l|l|l|}
\hline $\begin{array}{c}\text { Formula- } \\
\text { tions }\end{array}$ & Angle of repose $\mathbf{(}^{\mathbf{0}} \mathbf{c}$ & $\begin{array}{c}\text { Bulk density } \\
(\mathbf{g m} / \mathbf{c c})\end{array}$ & $\begin{array}{c}\text { Tapped density } \\
(\mathbf{g m} / \mathbf{c c})\end{array}$ & $\begin{array}{c}\text { Carr's index } \\
(\boldsymbol{\%})\end{array}$ & Hausner's ratio \\
\hline F1 & $25.56 \pm 0.015$ & $0.849 \pm 0.001$ & $0.903 \pm 0.001$ & $5.98 \pm 0.01$ & $1.063 \pm 0.002$ \\
\hline F2 & $25.64 \pm 0.01$ & $0.852 \pm 0.001$ & $0.906 \pm 0.002$ & $5.96 \pm 0.03$ & $1.063 \pm 0.003$ \\
\hline F3 & $25.76 \pm 0.0057$ & $0.854 \pm 0.002$ & $0.909 \pm 0.002$ & $6.05 \pm 0.04$ & $1.064 \pm 0.001$ \\
\hline F4 & $25.84 \pm 0.01$ & $0.857 \pm 0.002$ & $0.914 \pm 0.001$ & $6.23 \pm 0.05$ & $1.066 \pm 0.001$ \\
\hline F5 & $25.78 \pm 0.015$ & $0.859 \pm 0.001$ & $0.917 \pm 0.003$ & $6.32 \pm 0.05$ & $1.067 \pm 0.003$ \\
\hline F6 & $26.08 \pm 0.0057$ & $0.859 \pm 0.003$ & $0.911 \pm 0.003$ & $5.7 \pm 0.12$ & $1.06 \pm 0.002$ \\
\hline F7 & $25.70 \pm 0.0057$ & $0.854 \pm 0.002$ & $0.909 \pm 0.001$ & $6.05 \pm 0.04$ & $1.064 \pm 0.002$ \\
\hline F8 & $25.74 \pm 0.01$ & $0.857 \pm 0.002$ & $0.914 \pm 0.002$ & $6.23 \pm 0.10$ & $1.066 \pm 0.001$ \\
\hline F9 & $25.83 \pm 0.015$ & $0.857 \pm 0.001$ & $0.911 \pm 0.003$ & $5.92 \pm 0.02$ & $1.063 \pm 0.001$ \\
\hline F10 & $26.02 \pm 0.0057$ & $0.854 \pm 0.001$ & $0.909 \pm 0.001$ & $6.05 \pm 0.04$ & $1.064 \pm 0.001$ \\
\hline
\end{tabular}

All values are expressed as mean $\pm S D(n=3)$

\section{EVALUATION OF FORMULATION:}

Preparation of standard calibration curve of Alendronate sodium:

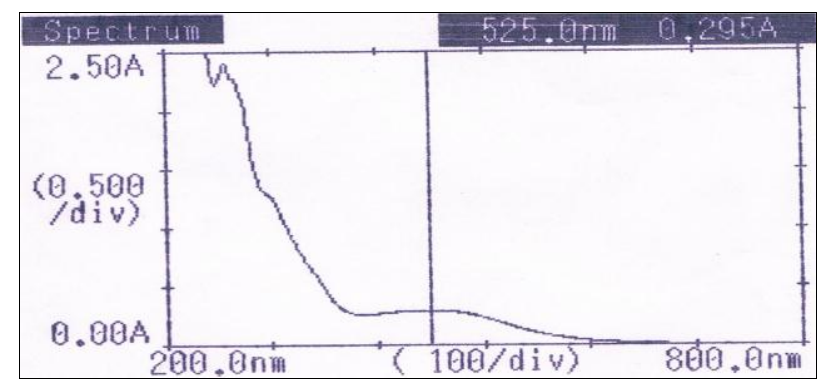

Figure 9: UV-spectrum of Alendronate sodium in distilled water

Table 4: Absorbance data of Alendronate sodium

\begin{tabular}{|c|c|c|}
\hline Sr. No. & Concentrations $(\boldsymbol{\mu g} / \mathbf{m l})$ & Absorbance \\
\hline 1. & 10 & 0.037 \\
\hline 2. & 20 & 0.072 \\
\hline 3. & 30 & 0.109 \\
\hline 4. & 40 & 0.146 \\
\hline 5. & 50 & 0.183 \\
\hline 6. & 60 & 0.222 \\
\hline
\end{tabular}

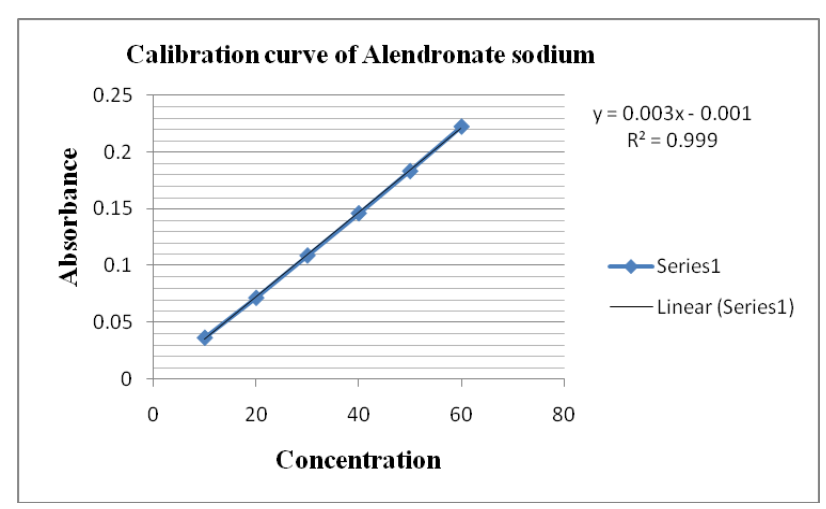

Figure 10: Calibration curve of Alendronate sodium. 
Table 5: Evaluation of Thickness, Hardness \& Weight variation

\begin{tabular}{|c|c|c|c|}
\hline Formulations & Thickness $\mathbf{( m m})$ & Hardness $\left.\mathbf{( k g} / \mathbf{~ c m}^{\mathbf{2}}\right)$ & Wright variation $\mathbf{( m g )}$ \\
\hline F1 & $5.95 \pm 0.005$ & $6.2 \pm 0.057$ & $4.328 \pm 0.014$ \\
\hline F2 & $5.95 \pm 0.01$ & $5.7 \pm 0.1$ & $4.305 \pm 0.005$ \\
\hline F3 & $5.94 \pm 0.015$ & $5.8 \pm 0.152$ & $4.3 \pm 0.01$ \\
\hline F4 & $5.96 \pm 0.01$ & $6.0 \pm 0.152$ & $4.29 \pm 0.015$ \\
\hline F5 & $5.99 \pm 0.021$ & $5.7 \pm 0.2$ & $4.303 \pm 0.006$ \\
\hline F6 & $6.03 \pm 0.015$ & $5.3 \pm 0.1$ & $4.336 \pm 0.013$ \\
\hline F7 & $5.97 \pm 0.02$ & $5.9 \pm 0.057$ & $4.315 \pm 0.011$ \\
\hline F8 & $5.98 \pm 0.005$ & $5.9 \pm 0.1$ & $4.338 \pm 0.005$ \\
\hline F9 & $5.96 \pm 0.01$ & $5.7 \pm 0.152$ & $4.325 \pm 0.013$ \\
\hline F10 & $6.0 \pm 0.005$ & $5.6 \pm 0.057$ & $4.314 \pm 0.005$ \\
\hline
\end{tabular}

All values are expressed as mean $\pm S D(n=3)$

Table 6: Evaluation of chromatograms Vitamin $D_{3}$ Table 7: Evaluation of chromatograms Vitamin $D_{3}$.

\begin{tabular}{|l|l|l|l|l|l|l|}
\hline \multirow{2}{*}{ Average } & Initial & \multicolumn{3}{c|}{$1^{\text {st }}$ Month $\left({ }^{0} \mathrm{C} / \mathrm{RH}\right)$} & \multicolumn{2}{c|}{$3^{\text {rd }}$ Month $\left({ }^{0} \mathrm{C} / \mathrm{RH}\right)$} \\
\cline { 3 - 7 } & & $25 / 60$ & $30 / 65$ & $40 / 75$ & $25 / 60$ & $30 / 65$ \\
\hline STD Area & 75867.8 & 75867.8 & 75867.8 & 75867.8 & 75867.8 & 75867.8 \\
\hline SPL Area & 180596.5 & 173537 & 169142.5 & 162812.5 & 164843 & 159485.5 \\
\hline SPL Wt. & 11.8512 & 12.2451 & 12.1024 & 11.9845 & 12.4456 & 12.3684 \\
\hline Tab. & 4.6125 & 4.6014 & 4.5987 & 4.6002 & 4.5941 & 4.6102 \\
\hline
\end{tabular}

Table 7: Evaluation of Solution time, $\mathrm{pH}$ of solution \& Drug content

\begin{tabular}{|c|l|c|c|c|}
\hline Formulations & Solution time (sec.) & pH of solution & \multicolumn{2}{|c|}{ Drug content (\%) } \\
\cline { 3 - 5 } & & & ALS & Vit.D $_{\mathbf{3}}$ \\
\hline F1 & $60.33 \pm 0.079$ & $5.1 \pm 0.053$ & $99.70 \pm 0.080$ & $198.46 \pm 0.028$ \\
\hline F2 & $54.83 \pm 0.091$ & $5.04 \pm 0.050$ & $99.49 \pm 0.069$ & $198.22 \pm 0.026$ \\
\hline F3 & $56.09 \pm 0.096$ & $5.42 \pm 0.025$ & $99.33 \pm 0.060$ & $196.34 \pm 0.035$ \\
\hline F4 & $58.49 \pm 0.09$ & $5.54 \pm 0.045$ & $99.17 \pm 0.083$ & $196.94 \pm 0.036$ \\
\hline F5 & $51.54 \pm 0.115$ & $6.03 \pm 0.015$ & $99.05 \pm 0.092$ & $198.30 \pm 0.03$ \\
\hline F6 & $47.46 \pm 0.101$ & $5.85 \pm 0.030$ & $99.33 \pm 0.063$ & $197.04 \pm 0.015$ \\
\hline F7 & $42.83 \pm 0.110$ & $5.68 \pm 0.020$ & $99.38 \pm 0.081$ & $196.7 \pm 0.020$ \\
\hline F8 & $43.08 \pm 0.106$ & $5.58 \pm 0.036$ & $99.60 \pm 0.072$ & $197.26 \pm 0.025$ \\
\hline F9 & $56.42 \pm 0.085$ & $5.52 \pm 0.025$ & $99.54 \pm 0.057$ & $197.7 \pm 0.03$ \\
\hline F10 & $57.58 \pm 0.090$ & $5.7 \pm 0.020$ & $99.65 \pm 0.029$ & $199.13 \pm 0.026$ \\
\hline
\end{tabular}

All values are expressed as mean $\pm S D(n=3)$

Table 8: Taste Analysis of Formulations

\begin{tabular}{|c|c|c|c|c|c|}
\hline \multirow{2}{*}{ Formulations } & \multicolumn{5}{|c|}{ Volunteer } \\
\cline { 2 - 6 } & I & II & III & IV & V \\
\hline F1 & Very sour & Very sour & Very sour & Very sour & Very sour \\
\hline F2 & Very sour & Sour & Sour & Very sour & Sour \\
\hline F3 & $\begin{array}{c}\text { Slightly sour, } \\
\text { good }\end{array}$ & $\begin{array}{c}\text { Slightly sour, } \\
\text { good }\end{array}$ & Sour & $\begin{array}{c}\text { Very slightly } \\
\text { sour, good }\end{array}$ & Slightly sour \\
\hline F4 & Good but sweet & Good but sweet & Good but sweet & Good but sweet & Good \\
\hline F5 & Basic, sweet & $\begin{array}{c}\text { Basic, very } \\
\text { sweet }\end{array}$ & $\begin{array}{c}\text { Basic, very } \\
\text { sweet }\end{array}$ & $\begin{array}{c}\text { Basic, very } \\
\text { sweet }\end{array}$ & $\begin{array}{c}\text { Basic, very } \\
\text { sweet }\end{array}$ \\
\hline F6 & after metallic & after metallic & after metallic & after metallic & after metallic \\
\hline F7 & after metallic, & $\begin{array}{c}\text { after metallic, } \\
\text { slightly bitter }\end{array}$ & $\begin{array}{c}\text { after metallic, } \\
\text { slightly bitter }\end{array}$ & $\begin{array}{c}\text { after metallic, } \\
\text { excess polo }\end{array}$ & $\begin{array}{c}\text { after metallic, } \\
\text { slightly bitter }\end{array}$ \\
\hline F8 & Sweet & ok & Sweet & Sweet & Sweet \\
\hline F9 & $\begin{array}{c}\text { Strong orange } \\
\text { feel, good }\end{array}$ & ok & $\begin{array}{c}\text { Strong orange } \\
\text { feel, good }\end{array}$ & $\begin{array}{c}\text { Strong orange } \\
\text { feel, good }\end{array}$ & ok \\
\hline F10 & ok & ok & ok & ok & ok \\
\hline
\end{tabular}




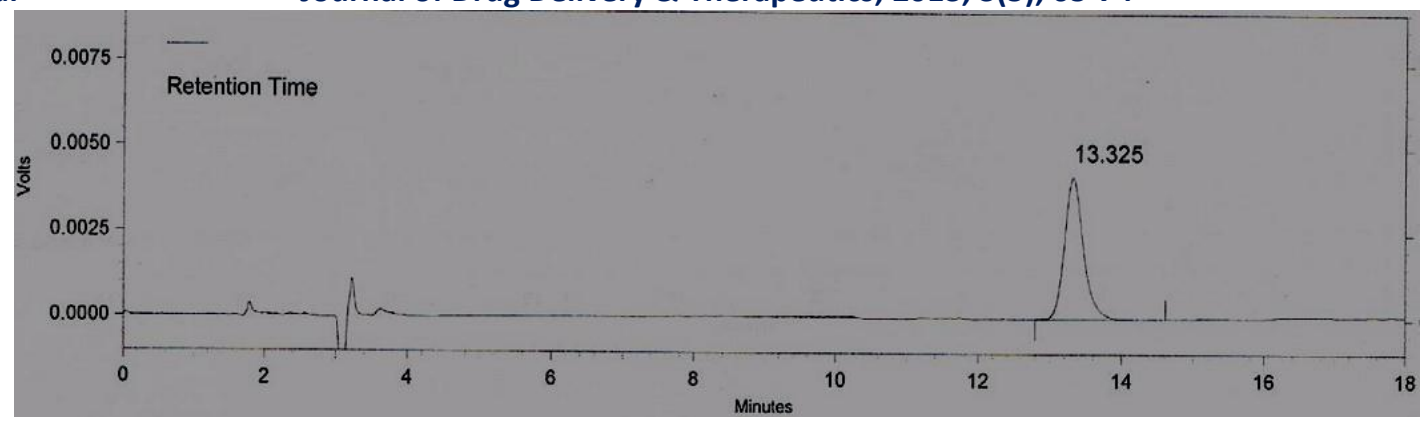

Figure 11: Chromatogram of Vitamin $D_{3}$ Standard solution.

\section{STABILITY STUDIES:}

Table 9: Evaluation of Formulation (F10) after $1^{\text {st }}$ Month

\begin{tabular}{|l|c|c|c|c|c|c|}
\hline & Appearance & \multirow{2}{*}{$\begin{array}{c}\text { Hardness } \\
\left(\mathbf{K g} / \mathbf{c m}^{\mathbf{2}}\right)\end{array}$} & $\begin{array}{c}\text { Solution time } \\
(\mathbf{S e c} .)\end{array}$ & $\begin{array}{c}\text { pH of } \\
\text { solution }\end{array}$ & \multicolumn{2}{c|}{ \% content } \\
\cline { 5 - 7 } & & $5.7 \pm 0.1$ & $58.49 \pm 0.09$ & $5.72 \pm 0.020$ & $99.21 \pm 0.015$ & $184.75 \pm 0.025$ \\
\hline $25^{\circ} \mathrm{C} / 60 \% \mathrm{RH}$ & Orange colored & 5.75 & Vit. $\mathbf{D}_{\mathbf{3}}$ \\
\hline $30^{\circ} \mathrm{C} / 65 \% \mathrm{RH}$ & Orange colored & $5.7 \pm 0.152$ & $58.76 \pm 0.091$ & $5.73 \pm 0.030$ & $99.13 \pm 0.030$ & $182.09 \pm 0.032$ \\
\hline $40^{\circ} \mathrm{C} / 75 \% \mathrm{RH}$ & Orange colored & $5.7 \pm 0.2$ & $58.98 \pm 0.115$ & $5.73 \pm 0.025$ & $99.01 \pm 0.026$ & $177.05 \pm 0.028$ \\
\hline
\end{tabular}

Table 10: Evaluation of Formulation (F10) after $3^{\text {rd }}$ Month

\begin{tabular}{|c|c|c|c|c|c|c|}
\hline & \multirow[t]{2}{*}{ Appearance } & \multirow{2}{*}{$\begin{array}{c}\text { Hardness } \\
\left(\mathrm{Kg} / \mathrm{cm}^{2}\right)\end{array}$} & \multirow{2}{*}{$\begin{array}{l}\text { Solution time } \\
\text { (Sec.) }\end{array}$} & \multirow[t]{2}{*}{ pH of solution } & \multicolumn{2}{|c|}{$\%$ content } \\
\hline & & & & & ALS & Vit. $D_{3}$ \\
\hline $25^{\circ} \mathrm{C} / 60 \% \mathrm{RH}$ & Orange colored & $5.8 \pm 0.115$ & $60.33 \pm 0.079$ & $5.75 \pm 0.020$ & $98.82 \pm 0.025$ & $172.39 \pm 0.030$ \\
\hline $30^{\circ} \mathrm{C} / 65 \% \mathrm{RH}$ & Orange colored & $5.8 \pm 0.152$ & $60.57 \pm 0.079$ & $5.76 \pm 0.015$ & $98.69 \pm 0.026$ & $168.42 \pm 0.025$ \\
\hline
\end{tabular}

All values are expressed as mean $\pm S D(n=3)$

\section{DISCUSSION:}

The procured sample of Alendronate sodium and Vitamin $\mathrm{D}_{3}$ was characterized by organoleptic properties, melting point, UV, FTIR and DSC analysis that confirmed the purity of the drug. The DSC analysis showed no significant shift in the endothermic peak \& FTIR analysis showed absence of any characteristics peaks of pure drug, which confirms the absence of chemical interaction between drug and excipients. Flowability studies result indicates good-excellent flow properties of the powder mixture. The thickness of the tablet signify uniformity and it was due to uniformity in die fill, good flow properties, uniform pressure and appropriate punch movement. All the formulations are within the limit of weight variation. Hardness was found to be in the range of $5.3 \mathrm{~kg} / \mathrm{cm}^{2}$ to $6.4 \mathrm{~kg} / \mathrm{cm}^{2}$.

Formulations of various effervescent composition show variation in the $\mathrm{pH}$ of solutions and In-vivo taste evaluation by panel test, formulation F10 shows more popularity and having better taste than others. Content uniform of Alendronate sodium \& Vitamin $\mathrm{D}_{3}$ is within the (C) 2011, JDDT. All Rights Reserved limit as per USP specification. It indicates that all formulations have the dose uniformity. ${ }^{23}$

From the stability study results it was observed that there was no significant change in physiochemical properties even after storage at various temperature and humidity conditions for three months. It may be inferred that there was no degradation and change in the formulation.

\section{CONCLUSIONS:}

The Effervescent tablet of Sodium Alendronate and Vitamin $D_{3}$ is a new pharmaceutical formulation to be taken orally and offering a considerable advantage: avoidance of gastro-intestinal disorders, to the limits of the possible. Another aspect of this invention is that the absorption of the active ingredient is faster when compared to the tablet form; consequently an enhanced bioavailability of the active ingredient is probable. As compared to the pure drug and marketed tablet, effervescent tablet of Alendronate sodium plus Vitamin $\mathrm{D}_{3}$ 
displayed significantly effective in the oral osteoporosis treatment in post menopausal women.

\section{ACKNOWLEDGMENTS:}

With great pleasure and profound sense of gratitude, i express my most cordial and humble thanks to Apex Healthcare Ltd., Ankleshwar (Gujarat) for providing me

\section{REFERENCES:}

1. K.R. Srinath, "Formulation and Evaluation of Effervescent tablets of Paracetamol", International Journal of Pharmaceutical Research \& Development, 2011, Vol. 3(3): 12, 76- 104.

2. A.K.L. Kabir, "Formulation Development of Verapamil Hydrochloride Tablet by Effervescent Method", Stamford Journal of Pharmaceutical Sciences, 2010, 3(1), 34-37.

3. H. Stahl, "Effervescent Dosage", Pharmaceutical Technology Europe Magazine, April 2003, 25-28.

4. F. Karamustafa, "Bisphosphonate and Alendronate- Scientific Review”, FABAD J. Pharm. Sci., 2006, 31, 31-42.

5. Teva Pharmaceuticals USA, "Highlights of Prescribing Information of Alendronate Sodium Tablet", May 2012, 1-30.

6. Merck Sharp \& Dohme Corp., "Full Prescribing Information for FOSAMAX”, Initial U.S. Approval: 1995; Revised: June 2012, 1-23.

7. Merck Sharp and Dohme Pvt. Ltd., "Product Information Fosamax and Fosamax Plus", TGA Approved, 9 May 2009, $1-27$

8. C.P. Peter, "Esophageal irritation due to alendronate sodium tablets: possible mechanisms", National Center for Biotechnology Information, 1998, 43(9).

9. A.V. Katdare, "Effervescent Alendronate Formulation", Patent no.: US 5,853,759, 1998, 1-4.

10. G.A. Daifotis, "Combination for Inhibiting Bone Resorption Comprising a Bisphosphonate (Alendronate) and a Vitamin d (Cholecalciferol)", Publication no.: EP1758594 A1, 2007, 15 .

11. S.K. Niazi, "Handbook of Preformulation", Informa Healthcare USA, Inc.; 2007. P. 69, 73, 241, 218, 219, 294, 296, 310-31

12. M.C. Adeyeye \& H.G. Brittain, "Preformulation in Solid Dosage Form Development", Volume 178, Informa Healthcare USA, Inc.; 2008. P. 369, 559, 562, 565-567.

13. M. Gibson, "Pharmaceutical Preformulation And Formulation", IHS Health Group; 2004. P. 2, 39, 48, 50, 58, $66,188,227,22$
Alendronate sodium bulk sample and Mr. Pradip Gadre, Managing Director, Mr. Anand Athavale, Technical Director, SciTech Specialities Pvt. Ltd. Sinnar, for their valuable guidance, keen interest, inspiration, unflinching encouragement and moral support throughout my dissertation work and providing me basic facility.

14. M.E. Aulton, "Phramaceutics- The Science of Dosage form Design", $2^{\text {nd }}$ ed. Churchill livingstone Publication; P. $205-$ 208.

15. P. Palanisamy, "Formulation and Evaluation of Effervescent Tablet of Aceclofenac", International Research Journal of Pharmacy, 2011, 2(12), 185-190.

16. A. Patidar, "A Review on- Recent Advancement in The Development of Rapid Disintegrating Tablet", International Journal of Life Science \& Pharma Research, 2011, Vol. 1, Issue 1, 7-16.

17. A. Aslani, "Formulation, Characterization and Physicochemical Evaluation of Potassium Citrate Effervescent Tablets", Advanced Pharmaceutical Bulletin, 2013, 3(1), 217-225.

18. H.K. Patel, "Formulation and Evaluation of Effervescent Tablet of Paracetamol and Ibuprofen", International Journal for Pharmaceutical Research Scholars, 2012, Vol. 1, I-2, 509520.

19. S.S. Panda, "Spectrophotometric Determination of Alendronate Sodium by Using Sodium-1,2-Napthoquinone-4Sulphonate", International Journal of Pharmaceutical Sciences and Nanotechnology, 2012, Vol. 4, Issue 4, 15631568 .

20. British Pharmacopoeia, Seventh Edition, Published by The Stationery Office on behalf of the Medicines and Healthcare products Regulatory Agency (MHRA); 2009, Vol. 1\& 2. P. $1581,5413$.

21. S.B. Thoke, "Review On: Taste masking approaches and Evaluation of Taste Masking", International Journal of Pharmaceutical Sciences, 2012, 4(2), 1895-1907.

22. G. Rajalakshmi, "Formulation and Evaluation of Diclofenac Potassium Effervescent Tablets", International Journal of Pharmaceutical and Biomedical Research, 2011, 2(4), 237243.

23. U. S. Pharmacopoeia 30- NF 25; 2007. P. 1317, 1742. 